\title{
Severe Degree of The Obesity Has More Comorbid Factors and more Severe of The Knee Osteoarthritis
}

\author{
Natalia Loekito, Tirza Z. Tamin, I Nyoman Murdana
}

Department of Physical Medicine and Rehabilitation, University of Indonesia/ Cipto Mangunkusumo National Hospital, Jakarta, Indonesia.

\begin{tabular}{|c|}
\hline ABSTRACT \\
\hline $\begin{array}{l}\text { Background. Obesity is a risk factor for knee osteoarthritis (OA). The major problem of OA are pain and } \\
\text { decreased of knee muscle strength cause a decline of functional capacity, and lead to disability. Aim of this study is } \\
\text { to describe the profile of obese patients with knee OA to prevent disability. }\end{array}$ \\
\hline $\begin{array}{l}\text { Methods: A descriptive study was conducted from September } 2016 \text { - March } 2017 \text {. Subjects were obese patients } \\
\text { with knee } \mathrm{OA} \text {, age ranging from } 40-80 \text { years with sedentary lifestyle, with Physical activity level (PAL) }<1.4 \text {. }\end{array}$ \\
\hline $\begin{array}{l}\text { Results: Most of the subjects have age }>60 \text { y.o }(58,5 \%) \text { and were female }(92,7 \%) \text {. The frequency of Obesity grade } \\
\text { II }(56,1 \%) \text {, and OA knee grade III }(56,1 \%) \text { were the most frequent. There were higher prevalence of comorbid } \\
\text { factors on subjects with grade II of obesity i.e., hypertension, dyslipidemia, and diabetes mellitus ( } 32 \text { vs } 27,18 \mathrm{vs} \\
5,7 \text { vs } 2) \text { respectively. This study found } 41 \text { subjects has knee OA, consist grade II was } 18(43,9 \%) \text {, grade II was } \\
23(56,1 \%) \text {. Besides, there were higher prevalence of more severe knee OA on grade II than grade I of obesity } \\
\text { subjects ( } 29 \text { vs } 12) \text {. }\end{array}$ \\
\hline $\begin{array}{l}\text { Conclusions: Higher grading of obesity has more prevalence of comorbid factors, as well as has more severe of } \\
\text { knee OA. }\end{array}$ \\
\hline \\
\hline
\end{tabular}

\section{Correspondent Detail:}

\section{Natalia Loekita}

Email : natalia.loe25@gmail.com

Department of Physical Medicine and Rehabilitation,

University of Indonesia/ Cipto Mangunkusumo National Hospital, Jakarta, Indonesia.

Address: Jalan Pangeran Diponegoro No.71, Jakarta Pusat, DKI Jakarta, Indonesia. 


\section{INTRODUCTION}

Obesity is defined as abnormal or excessive fat accumulation that presents a risk to health (WHO, 2011). Obesity has become a global pandemic worldwide and is declared by WHO as the biggest chronic problem in adults. In Indonesia the prevalence of obesity keep on rising and DKI Jakarta is above national prevalence. ${ }^{1}$ Based on data of Medical Rehabilitation Department - Cipto Mangunkusumo Hospital, there is an increasing number of patient visiting Obesity Policlinic from year to year (in 2013 there is 1484 visits, then in 2014 increase to 2287 visits, and the last data in 2016 is 2472 visits).

Obesity is associated with a variety of health problems, like heart disease, hypertension, diabetes mellitus, and also musculoskeletal disorders that have an impact on declining functional capacity. The most common of musculoskeletal disorders is osteoarthritis (OA). The most commonly affected joints is weight bearing joint like knee. ${ }^{2}$ According to Sturmer et $\mathrm{al}^{3}$, the incidence of knee OA increased twice as much in obese people. In obesity there is an increase in mechanical strength across the joints in the burden which is the main factor causing joint degeneration. ${ }^{2}$ It also found that adipose tissue is an endocrine organ of metabolites that produce adipocytokines such as leptin, resistin and adiponectin that play a role in joint degeneration. ${ }^{4}$ Leptin is generally higher in individuals with obesity.

Knee OA is the cause of pain and disability that need to high cost of health care and rehabilitation.5,6 Disability associated with knee OA has many factors i.e., sociodemographic, radiographic severity, knee pain, comorbid conditions (hypertension, diabetes, dyslipidemia), and psychological factors.7 Decreased of muscle strength due to of inactivity because of pain, caused knee joint deformity and the pain worsening which lead to disability. In other hand obesity reduces cardiorespiration and large muscles endurance as well that caused limitation in perform activity, and lead to disability.8,9

Management of obesity with knee OA is very important to reduce pain, optimize knee joint function and aerobic capacity so as to reduce the limitations of daily physical activity and to improve quality of life.10 Management includes lifestyle modification, diet and physical exercise including aerobic and muscle strengthening of the knee joint. Therapeutic exercise for patients with obesity and knee OA needs more consideration because of there are comorbid of obesity, i.e., hypertension, diabetes mellitus, and dyslipidemia.11 Cipto Mangunkusumo Hospital as the main referral hospital of Indonesia, which received patients with complicated health problem. The profile of the obesity patients with knee OA such as age, sex, grade of obesity and knee OA, as well as comorbidity are important to inventory as a data base, to create the proper of therapeutic exercise program.

The aim of this study is to describe the profile 
of the patients with obesity and knee OA in Obesity Clinic of Rehabilitation Department Cipto Mangunkusumo Hospital.

\section{MATERIAL AND METHODS}

\section{Study Design, Place and Participants}

Design study was descriptive study at Obesity Clinic of Rehabilitation Department - Cipto Mangunkusumo Hospital. Subjects were recruited from the patients who registered at the obesity clinic by consecutive sampling. Criteria inclusion was patients age 40 years and above, with body mass index (BMI) more than $25 \mathrm{~kg} / \mathrm{m}^{2}$ body, have sedentary lifestyle, able to walk independently without walking devices. Subjects were excluded if they had vision and hearing disorders, and cognitive impairment (MMSE <23). Data description in univariate of frequency and percentage. Knee OA classification by Kellgren-Lawrence radiograph $\mathrm{x}$ ray classification (grade I-IV). This study's protocol was approved by the Ethics Committee of the Faculty of Medicine, University of Indonesia.

\section{RESULTS}

The number of subjects was 41, who underwent the initial evaluation will be assessed for sociodemographic status and comorbids. They have onset of knee OA for 2,9 $\pm 2,3$ years and obesity for $11,1 \pm 7,8$ years. The mean age was 60,5 $\pm 8,3$ years old with the body weight $70,6 \pm$ $10,5 \mathrm{~kg}$ and body height $153,1 \pm 6,3 \mathrm{~cm}$, and waist circumference $94,3 \pm 7,6 \mathrm{~cm}$. Subject characteristic can be seen in table 1 .

Table 1. Characteristics of subjects $(n=41)$

\begin{tabular}{lc}
\multicolumn{1}{c}{ Characteristic } & $\mathbf{n}(\mathbf{\%})$ \\
\hline Age & \\
$<60$ years old & $17(41,5 \%)$ \\
$\geq 60$ years old & $24(58,5 \%)$ \\
Sex & \\
Male & $3(7,3 \%)$ \\
Female & $38(92,7 \%)$ \\
Employment status (\%) & \\
Housewife & $31(75,6 \%)$ \\
Employee & $7(17,1 \%)$ \\
Retired & $3(7,3 \%)$ \\
Education (\%) & \\
Senior High School & $19(46,3 \%)$ \\
Bachelor & $22(53,7 \%)$ \\
Comorbid (\%) & \\
Hypertension & $30(73,2 \%)$ \\
Diabetes Mellitus & $5(12,2 \%)$ \\
Dyslipidemia & $12(29,3 \%)$ \\
Severity of Knee OA & \\
grade II & $18(43,9 \%)$ \\
grade III & $23(56,1 \%)$ \\
Nutritional status & \\
Obesity Grade I (IMT $\left.25,0-29,9 \mathrm{~kg} / \mathrm{m}^{2}\right)$ & $18(43,9 \%)$ \\
Obesity Grade II (IMT $\left.\geq 30 \mathrm{~kg} / \mathrm{m}^{2}\right)$ & $23(56,1 \%)$ \\
\hline
\end{tabular}


In this study, a comparison prevalence of comorbid and severity of OA between obesity grade I and obesity grade II was made.

Table 2. Distribution frequency of chronic disease on Grade I and Grade II of obesity

\begin{tabular}{lccc}
\hline Grade of obesity & $\begin{array}{c}\text { Hypertension } \\
\mathbf{n}(\%)\end{array}$ & $\begin{array}{c}\text { Diabetes mellitus } \\
\mathbf{n}(\%)\end{array}$ & $\begin{array}{c}\text { Dyslipidemia } \\
\mathbf{n}(\%)\end{array}$ \\
\hline Grade I & $27(66,7 \%)$ & $2(5,4 \%)$ & $5(11 \%)$ \\
Grade II & $32(78,3 \%)$ & $7(17,4 \%)$ & $18(43,5 \%)$ \\
\hline
\end{tabular}

Table 2 showed the subjects with grade II of obesity have higher prevalence of Hypertension, Dyslipidemia, and Diabetes mellitus respectively, compared to the subjects with grade I of obesity.

Table 3. Distribution frequency of Knee OA grade II and III on grade I and II of obesity

\begin{tabular}{ccc} 
Grade of obesity & Knee OA grade II & Knee OA grade III \\
\hline Grade I & $25(61 \%)$ & $12(30 \%)$ \\
Grade II & $16(39 \%)$ & $29(70 \%)$ \\
\hline
\end{tabular}

Data in Table 3 showed subjects with grade II of obesity have higher prevalance of grade III of knee OA compared to the obesity grade I.

\section{DISCUSSION}

\section{Risk Factors in Knee Osteoarthritis}

The mean age of subjects with obesity and knee OA was $60,5 \pm 8,3$ years, and more than $50 \%$ of subjects were older than 60 years old. This study supported Lim (2010) that found 70\%-80\% of the population who are older than 55 years have degenerative changes in their joints. 12 According to previous studies, among the established biological and lifestyle-related risk factors for OA, e.g., genetic factors, congenital joint deformities, joint injury, occupational physical activity, and obesity; age is regarded as the most prominent risk factor for the initiation and progression of OA.5,6,13 The association between OA and age is believed to be caused by age-related increases in bio-mechanical risk factors such as obesity, weakened neuromuscular joint protection mechanisms, increased joint instability, decreased elasticity and reduced cartilage regeneration.14 The aging process increase joint susceptibility through several mechanisms, such as old cartilage is lacking responsive to dynamic load stimuli, the muscles of the knee joint become weaker and reacts more slowly to impulses.2,8 In addition, at the age of 50-60 years on physiologically began to 
increase fat mass. This adipose cell produces leptin that is thought to have an important role in the onset and progresivitas OA.8 Combinations of those factors increase joint susceptibility to OA.

The subjects consist of 38 females and 3 males which was in line with study from Lim (2010) in Korea which shows more than $80 \%$ of the overall subjects is female. 12 It is also supported by Framingham studies that women are at 1.8 times greater risk than men to experience knee OA.12 The prevalence and incidence of $\mathrm{OA}$ at older age is higher in women than men. For instance for clinical and radiographic OA of the knee in women at age $60-69$ years the prevalence has been estimated at $14.9 \%$ and the incidence at 658 per 100,000 personyears, respectively, while the corresponding prevalence and incidence estimates in men are $7.9 \%$ and 487 per 100,000 person-years, respectively.8,17 Based on previous study, the higher prevalence of knee OA in women and increased incidence OA in postmenopausal women suggest the likely existence of systemic factors in the pathogenesis of OA. Systemic factors that play a role in the pathogenesis of OA include body composition, regulation of lipid homeostasis regulation, and disturbance of hormonal regulation in women.17 (Figure 3) According to the RISKESDAS 2013, the prevalence of adult female obesity is $32.9 \%$, up $18.1 \%$ from 2007 and $17.5 \%$ from 2010 compared to the prevalence of obesity in adult men as much as $19.7 \%$ higher than in 2007 (13, 9\%).1 According to the visiting data from
Obesity Polyclinic - Department of Medical Rehabilitation Cipto Mangunkusumo Hospital, the majority of patients are women.

Most subjects are housewives who are actively engaged in household chores with repeated knees bent positions, such as washing clothes, mopping, ect. It is in line with study from Klussman (2010) and demographic data of Jakarta population which state there is an increased risk of OA in subjects whose primary job is to kneel or squat over 30 minutes per day and also housewives have more time to go to health services regularly.18,19 Theoretically, excessive and repetitive loads on the weightbearing support joints, will trigger biological changes that will lead to changes in joints, including changes in the water content, proteoglycan content, and collagen in cartilage joints which lead to OA. Most of the subjects are bachelor so that they have good awareness about their health and go to medical center to seek treatment. 20

The severity of knee OA was grade II-III of Kellgren-Lawrence. Result of the study have shown the subjects with obesity grade II have higher prevalence of grade II of knee OA compared to obesity grade I. This data supported the study by Anestherita F (2013)21

\section{Chronic Disease on Grade I and Grade II of obesity}

Subjects with grade II of obesity have higher percentation of hypertension, type 2 diabetes mellitus, and hyperlipidemia, compared to 
grade I of obesity. These chronic diseases are the comorbid of obesity. This study supported the previous study has found that comorbid of obesity were cardiovascular and metabolic diseases. 22

Obesity is associated with atherosclerosis, which lead to disrupt the arterial walls, and caused many problems such a retinopathy and renal vascular disease, increased sympathetic nerve, and changes of endothelial dysfunction and vascular structural, which caused increasing the risk of hypertension. ${ }^{10,23,24}$

Subjects with obesity has a higher risk of type 2 diabetes, because of several factors i.e., changes in insulin resistance, decrease the amount of glucose transporters present in cell membranes, and decreasing the ability of cells to attract glucose from the blood. ${ }^{10,23}$

Blood lipids profiles are changes in obesity i.e.; raising blood cholesterol levels, increasing LDL cholesterol (accelerating the accumulation of cholesterol in blood vessel walls), decreasing HDL-cholesterol (preventing cholesterol accumulation in blood vessel walls). ${ }^{10,23}$

Data from this study have shown that hypertension, diabetes mellitus, and dyslipidemia were higher in patient with obesity garde II compared to obesity grade I. This study result supported the study from The Profesional's Health Study which showed increasing of the risk of type 2 diabetes mellitus on subjects with BMI $24-24.9 \mathrm{~kg} / \mathrm{m} 2$, and the risk was more increasing on subjects with BMI $>31 \mathrm{~kg} / \mathrm{m}^{2}$.

\section{CONCLUSION}

Subjects with obesity and knee OA were visiting the obesity clinic have average age $>60$ years old. The most subject were female, which has repetitive knee bending in household activities. Subjects with obesity grade II have higher proportion of the comorbids i.e hypertension, dyslipidemia, and diabetes mellitus, compare to subjects with obesity grade I. Subjects with obesity grade II have more severe of the knee OA as well. Higher grade of obesity has increasing on comorbid diseases, and more severe of knee $\mathrm{OA}$, and may has consequences in increasing of the disability. Further study is necessary to analyze the effect of therapeutic exercise on obesity, to prevent disability on elderly.

\section{REFERENCE}

1. Trihono. Riset Kesehatan Dasar [online]. 2013[cited 2017 Sep 20]. Available from: URL: http://www.depkes.go.id/resources/ download/general/Hasil\%20Riskesdas\%20 2013.pdf

2. SitikTP, StiskalD, FoyeP, etal.Osteoarthritis. In: Frontera WR, ed. DeLisa's physical medicine and rehabilitation: principles and practice. Philadelphia: Lippincott Williams \& Wilkins; 2010: 781-809.

3. Sturmer T, Gunther KP, Brenner H. Obesity, overweight and patterns of osteoarthritis: the ulm osteoarthritis study. J Clin Epidemiol 2000 Mar; 53(3): 307-13.

4. Sowers MR, Karvonen-Gutierrez CA. The evolving role of obesity in knee 
osteoarthritis. Curr Opin Rheumatol 2010 Sep; 22(5): 533-7.

5. Garstang SV, Stitik TP. Osteoarthritis: epidemiology, risk factors, and pathophysiology. Am J Phys Med Rehabil 2006 Nov; 85(11 Suppl): S2-11; quiz S124.

6. Sharma L, Kapoor D, Issa S. Epidemiology of osteoarthritis: an update. Curr Opin Rheumatol 2006 Mar; 18(2) :147-56.

7. Jordan JM, Luta G, Renner JB, et al. Selfreported functional status in osteoarthritis of the knee in a rural southern community: the role of sociodemographic factors, obesity, and knee pain. Arthritis Care Res Off J Arthritis Health Prof Assoc 1996 Aug; 9(4) :273-8.

8. DiCisare PE, Abramson SB, Samuels J. Pathogenesis of osteoarthritis. In: Firestein GS, Budd RC, eds. Kelley's textbook of rheumatology. Philadelphia: Saunders; 2012 : 1617-35.

9. Sturm R. The effects of obesity, smoking, and drinking on medical problems and costs. Health Aff Proj Hope 2002 Apr; 21(2): 24553.

10. Hoffman D, Gallagher. Obesity and weight control. In: Gonzales EG, Myers SJ, eds. Downey and Darling's physiological basis of rehabilitation medicine. Boston: Butterworth-Heinemann; 2001: 485-505.

11. Foley A, Halbert J, Hewitt T, et al. Does hydrotherapy improve strength and physical function in patients with osteoarthritis - a randomised controlled trial comparing a gym based and a hydrotherapy based strengthening programme. Ann Rheum Dis 2003 Dec; 62(12): 1162-7.

12. Lim JY, Tchai E, Jang SN. Effectiveness of aquatic exercise for obese patients with knee osteoarthritis: a randomized controlled trial. PMR 2010 Aug; 2(8): 723-3.

13. Hugle T, Gle T, Geurts J, et al. Aging and osteoarthritis: an inevitable encounter? J Aging Res 2012 Mar; 2012: 1-7.

14. Jorgensen KT, Pedersen BV, Nielsen NM, et al. Socio-demographic factors, reproductive history and risk of osteoarthritis in a cohort of 4.6 million Danish women and men. Osteoarthritis Cartilage 2011 Oct; 19(10): 1176-82.

15. Quintana JM, Arostegui I, Escobar A, et al. Prevalence of knee and hip osteoarthritis and the appropriateness of joint replacement in an older population. Arch Intern Med 2008 Jul; 168(14): 1576-84.

16. Srikanth VK, Fryer JL, Zhai G, et al. A meta-analysis of sex differences prevalence, incidence and severity of osteoarthritis. Osteoarthritis Cartilage 2005 Sep; 13(9): 769-81.

17. Teichtahl AJ, Wang Y, Wluka AE, et al. Obesity and knee osteoarthritis: new insights provided by body composition studies. Obes Silver Spring Md 2008 Feb; 16(2): 232-40.

18. Klussmann A, Gebhardt H, Nubling M, et al. Individual and occupational risk factors for knee osteoarthritis: results of a case-control study in Germany. Arthritis Res Ther 2010; 12(3): R88.

19. Pemprov DKI Jakarta. Data Penduduk 
DKI Jakarta Berdasarkan Pekerjaan Tahun 2014 [online]. 2014 [cited 2017 Sep 20]. Available from: URL: http://data. jakarta.go.id/dataset/datapendudukdkij akartaberdasarkanpekerjaan

20. Pemprov DKI Jakarta. Data Penduduk DKI Jakarta berdasarkan Pendidikan Tahun 2014 [online]. 2014 [cited 2017 Sep 20]. Available from: URL: http://data.jakarta. go.id/dataset/datadkimenurutpendidikan

21. Anestherita F. Perbandingan intensitas nyeri, kekuatan otot kuadrisep dan kemampuan fungsional lutut pada obesitas dan tanpa obesitas : studi potong lintang pada perempuan dewasa dengan osteoartritis genu [tesis]. Jakarta: Universitas Indonesia; 2013.
22. Wilborn C, Beckham J, Campbell B, et al. Obesity: prevalence, theories, medical consequences, management, and research directions. J Int Soc Sports Nutr 2005 Dec; 2(2): 4-31.

23. Roesnawi RP. Pengaruh kepatuhan latihan erobik terhadap profil lipid pada penderita obesitas tanpa komplikasi [tesis]. Jakarta: Universitas Indonesia; 2012.

24. Kotsis VV, Stabouli S, Papakatsika S, et al. Mechanisms of obesity-induced hypertension. Hypertens Res 2010 May; 33(5): 386-93.

25. Moore GE, Durstine JL, Painter PL. 